\title{
MJN HAND EXERCISE USING A RUBBER BALL INCREASES GRIP STRENGTH IN PATIENTS WITH NON-HAEMORRHAGIC STROKE
}

\author{
Ira Rahmawati ${ }^{1 *}$, Ratna Dewi ${ }^{2}$, Sumirah Budi Pertami ${ }^{1}$, Budiono$^{1}$, Ester Pasaribu ${ }^{2}$ \\ ${ }^{1}$ Department of Nursing, Poltekkes Kemenkes Malang, Indonesia \\ ${ }^{2}$ Department of Nursing, Faculty of Health, Esa Unggul University, Indonesia \\ *Corresponding Author's Email: irarahmawati.polkesma@gmail.com
}

\begin{abstract}
Stroke can cause various degrees of disturbance, such as decreased muscle tone, loss of sensibility in some parts of the body, limits the ability to move the affected limbs and incapacity in certain activities. This study aimed to identify the effect of hand exercises using a rubber ball on muscle strength in patients with nonhaemorrhagic stroke. we measure handgrip strengths of the respondents as it reflects the muscle strength and integrity functions of the upper limbs. The sample in this study was 40 patients with one-sided upper extremity paresis causing by ischaemic stroke. A pre-experimental method with one group pre-post-test design was used in this study. The respondents were given hand exercise using a ragged rubber ball for seven days twice a day. Handgrip strength of were measured by a handgrip dynamometer before and after the interventions. The Wilcoxon signed-rank test was performed with $p$-value of $0.000(\alpha<0,05)$ which means that hand exercises using a rubber ball does increase the muscle strengths of the upper extremity. We suggest that hand therapy using a ragged rubber ball can be used as an alternative for motor exercise in post-stroke patients.
\end{abstract}

\section{Stroke; Hemiparesis; Hand Exercises; Handgrip Strength; Handgrip Dynamometer}

\section{INTRODUCTION}

Stroke is one of the leading causes of mortality and disability with enormous economic costs globally. Stroke accounted for 5.5 million of deaths in 2016, with 2.7 million of the deaths were due to ischaemic stroke. Globally, Stroke is also the second leading cause of Disability-adjusted Life Years (DALYs) in 2016 (Feigin et al., 2019; Randolph, 2016). The prevalence of ischaemic stroke is higher than haemorrhagic stroke.

In Indonesia, stroke exerts a great economic burden on Indonesian Households, costing a total of Int $\$ 0,29$ billion in 2010 and is predicted to increase to Int $\$ 1,27$ billion in 2020 (Finkelstein, Chay \& Bajpai, 2014). According to the Ministry of Health of Indonesia (2018), there are 500.000 cases of stroke Indonesia each year, causing 12.500 deaths and leaving the rest disabled. $80 \%$ of the stroke are ischaemic and the rest $20 \%$ are haemorrhagic stroke (Ministry of Health Indonesia, 2018).

Stroke is defined as sudden onset of focal or global neurological deficits, lasting for more than 24 hours, or leading to death with no apparent cause other than a vascular origin. When the disruption of blood supply to the brain is caused by occlusion of the cerebral blood vessels, it is called ischaemic stroke. Meanwhile, haemorrhagic stroke is caused by a rupture of the cerebral blood vessels preventing blood flow to the brain Catangui \& Slark 2012; Hickey, 2013. Stroke may cause a various degree of disruption of the patients' psychological and physical functions. These include decrease in muscle tones, loss of sensibility and muscle strength of the affected body's parts and decrease of the ability to perform certain activities.

One of the most devastated sequelae of stroke is a loss of mobility. In Indonesia about $70 \%$ of the stroke case is non haemorrhagic stroke (Budiarto et al., 2014) and more than $70 \%$ of these patients were having weakness on one side of the body (Oktraningsih, 2017; Yazid, 2017). Paresis of the upper extremity is the most frequent motor problem experienced by individual with stroke (Carolee et al., 2016). Rehabilitation after stroke is indeed an important part of the stroke management and should be started early. However, the initiation of stroke rehabilitation within 24 hours may be not beneficial for the long-term outcomes or even harmful. 
Growing evidence suggests that constraint-induced movement therapy for the upper extremities may be significantly beneficial to be initiated within 2 weeks of stroke (Belagaje, 2017; Coleman et al., 2017).

Hand strength may be improved by resistance trainings, such as weight-bearing training, medicine balls, and elastic balls. Grasping a rubber ball can be used as an alternative for hand exercise, especially for patients with paresis of the upper extremities. Squeezing the ball will stimulate the upper extremity's muscles including fingers, hands, and wrists. It also stimulates the brain to coordinate the movement. In addition, grasping a rubber ball may help the muscles relax: gripping and releasing patterns lessen tension and stress. Several studies have used different means for the hand training resulted in varied results of muscles strength improvement (Prok, Gessal \& Angliadi, 2016).

This study aimed to evaluate the effect of hand training using a rubber ball on the muscle's strengths of the patients with hemiparesis after stroke. The exercise was conducted in the patients' home in an urban area of West Jakarta in March to June 2019. The muscle strengths of the affected hand were measured before and after the intervention using a handgrip dynamometer.

\section{METHODOLOGY}

This study employed a pre experimental one-group pre-post-test design. Forty stroke-survival individuals with weaknesses in one sided of the hands were recruited using purposive sampling method. The inclusion criteria were patients with non-haemorrhagic stroke with hemiparesis. All respondents were given hand exercise twice a day for fourteen days. We asked the individuals to squish a ragged rubber ball for five seconds then relaxed for five seconds. These procedures were repeated seven times for ten minutes. The hand strength was measured before and after interventions using handgrip dynamometer. Data analysis was conducted using Wilcoxon test, specifically to identify the difference of the patients' muscle strength before and after the intervention.

\section{RESULTS}

Table 1: Distribution of Respondent by Gender and Age Group

\begin{tabular}{|c|c|c|c|c|}
\hline $\begin{array}{c}\text { Age Group } \\
\text { (in Years) }\end{array}$ & $36-45$ & $46-55$ & $56-65$ & $>65$ \\
\hline Male & 2 & 15 & 4 & 2 \\
\hline Female & 1 & 10 & 5 & 1 \\
\hline $\mathrm{N}(\%)$ & $3(7.5 \%)$ & $25(62.5 \%)$ & $9(22.5 \%)$ & $3(7.5 \%)$ \\
\hline
\end{tabular}

The majority of our respondent were $45-55$ years old, that is $62,5 \%$ of the total sample. Meanwhile, respondent who were more than 65 years old were only three individuals. Table 1 also shows that more than a half of our respondent were male. Numerous studies have found that male is at high risk for stroke compared to pre menopause female (Förster et al., 2009; Haast, Gustafson \& Kiliaan, 2012; Watila et al., 2011).

Table 2: Mean Grip Strength of the Affected Hand Pre and Post Interventions Based on Age and Gender

\begin{tabular}{|c|c|c|c|c|c|c|c|c|}
\hline \multirow{2}{*}{$\begin{array}{c}\text { Age Group } \\
\text { (years) }\end{array}$} & \multicolumn{2}{|c|}{$36-45$} & \multicolumn{2}{|c|}{$46-55$} & \multicolumn{2}{|c|}{$56-65$} & \multicolumn{2}{|c|}{$>65$} \\
\cline { 2 - 9 } & pre & post & pre & post & pre & post & pre & post \\
\hline Male & 27.4 & 28.6 & 26 & 28.1 & 26.1 & 27.3 & 21.1 & 22.7 \\
\hline Female & 13.6 & 14.2 & 12.2 & 13.5 & 10.8 & 12.7 & 8.6 & 10.6 \\
\hline
\end{tabular}

Table 2 shows that the highest increase in grip strength was found in men at the age of $46-55$ years old. The handgrip strength increases by $2.1 \mathrm{mmHg}$.

Table 3: Mean Handgrip Strength of the Affected Hand Pre and Post Intervention

\begin{tabular}{|l|l|l|}
\hline Mean grip strength & Pre & Post \\
\cline { 2 - 3 } & 19.6 & 21.4 \\
\hline
\end{tabular}

\begin{tabular}{|c|c|c|c|c|c|c|}
\hline \multirow{2}{*}{$\begin{array}{c}\text { Ethical behavior } \\
\text { Domains }\end{array}$} & \multicolumn{2}{|c|}{$\begin{array}{c}\text { Private hospital } \\
\text { (89) }\end{array}$} & \multicolumn{2}{|c|}{$\begin{array}{c}\text { Teaching hospital } \\
\text { (105) }\end{array}$} & \multirow[t]{2}{*}{$T$} & \multirow[t]{2}{*}{$P$} \\
\hline & $\bar{x}$ & SD & $\bar{x}$ & SD & & \\
\hline Moral courage & 9.78 & 2.15 & 9.98 & 1.45 & $-0.747-$ & 0.45 \\
\hline Moral ownership & 7.93 & 1.194 & 8.12 & 1.16 & $-1.12-$ & 0.26 \\
\hline Moral efficacy & 13.24 & 1.91 & 13.34 & 1.64 & $-0.37-$ & 0.70 \\
\hline Total & 30.96 & 4.00 & 31.44 & 3.01 & $-0.95-$ & 0.34 \\
\hline
\end{tabular}

Statistical analysis using Wilcoxon signed ranks test was carried out to evaluate the effect of hand exercise using a rubber ball on hand grip strength.

Table 4: Comparison of Handgrip Strength Before and After Intervention

\begin{tabular}{|c|c|c|c|c|c|}
\hline & N & Mean & $\begin{array}{c}\text { Std. } \\
\text { Deviation }\end{array}$ & Z & $\begin{array}{c}\text { Asymp. Sig. } \\
\text { (2 tailed) }\end{array}$ \\
\hline $\begin{array}{c}\text { Grip strength } \\
\text { before } \\
\text { intervention }\end{array}$ & 40 & 19.625 & 7.4777 & $-5.513 \mathrm{~b}$ & 0.000 \\
\hline $\begin{array}{c}\text { Grip strength } \\
\text { after intervention }\end{array}$ & 40 & 21.423 & 7.6045 & & \\
\hline
\end{tabular}

Table 4 shows the 2 tailed value is $0,000<0,05$ meaning that there is a significant difference of the hand 
grip strength before and after intervention given.

\section{DISCUSSION}

Risk factors for stroke includes older age, smoking, high blood pressure, family history of stroke, ischaemic heart diseases, and consumption of birth control pills (Kelly-Hayes, 2010). Furthermore, as the incidence of metabolic disorders and cardiovascular diseases increase with age, the incidences of stroke will also increase after the age of 55 years old, and the risk is double every ten years after that ages. However, stroke may also occur in all age groups (Michael \& Shaughnessy, 2006). Indeed, the majority of our respondents were 45 - 55 years old and most of them have history of hypertension and smoking.

Studies have reported that handgrip strengths correlate with gender, dominant hands, age and also height and weight of the individuals (Agnew \& Maas, 1982; Kamarul, Ahmad \& Loh, 2006; Petersen et al., 1989). Measuring handgrip strengths using handgrip dynamometer can be used to predict the muscle strength. Handgrip strength test need only a simple handgrip dynamometer and minimal effort from individuals, such as post-stroke patients who might be unable to carry out the other heavy and complex test (Trosclair et al., 2011).

The value of handgrip strength as an indicator for arm recovery in post stroke patients have been studied and found that handgrip strength can be used to reflect the functional integrity of the upper extremity (McAniff \& Bohannon, 2002; Sunderland et al., 1989). Our study found that simple hand exercise at home could increase grip strength on the affected hand in post stroke patients. Decreased handgrip strength may reduce the ability to perform activity daily living (ADL) and therefore, affect the individuals' quality of life. A study also found that handgrip strength is associated with social and psychological functions (Taekema et al., 2010).

Hand strength may be improved by resistance training, such as grasping elastic ball weight-bearing training, medicine balls, and many others. In our study, we asked the individuals to squish a ragged rubber ball for five seconds then relaxed for five seconds. This procedure was repeated for seven time in 10 minutes twice a day for fourteen days. Grasping and releasing a ragged rubber ball for a certain period may stimulate acupressure points at the palm, which then activate the sensory neurons to send the impulse to the sensory areas of the affected hemisphere. Furthermore, squeezing a rubber ball with varied grip strength will train the muscles as well as the brain. Repeated hand exercise using a rubber ball or other tools such as cylindrical grips may help to increase muscles tones in several studies (Chaidir \& Zuardi, 2014; Irfan, 2012; Lindberg et al., 2004).

Physical training for stroke patients is to be initiated within 2 weeks because hand exercise very early within 24 hour of stroke attack may be harmful for the patients. All of the respondents in our study were in the rehabilitation phase, which was more than four weeks after stroke. Our study found that an increase of handgrips strange is higher in men than in women. The highest increase was found in men at the age group of 46 to 55 years old. Family support is one of the contributing factors to the training outcomes. Therefore, every step of the treatment given for patients with stroke should involve their next of kin or close family members. The family involvement is mostly crucial in the rehabilitation phase as wells as the stroke preventions programs (Rahmawaty et al., 2019).

\section{CONCLUSION}

Physical rehabilitation after stroke is an integral part of the stroke management and should be initiated early. Hand exercise using a rubber ball can be utilized as an alternative physical rehabilitation as it is cheap, simple, and easy to perform at home. The success of this exercise might be affected by several factors including the age of the responded and support from the family members.

\section{Conflict of Interests}

The authors declare that they have no conflict of interest.

\section{ACKNOWLEDGEMENT}

The authors are thankful to the institutional authority for completion of the work.

\section{REFERENCES}

Agnew, P.J. \& Maas, F. (1982). Hand function related to age and sex. Archives of Physical Medicine and Rehabilitation, 63(6), pp 269-271. 
Belagaje, S.R. (2017). Stroke Rehabilitation, Continuum (Minneap Minn), 23(1), pp 238-253.

Budiarto, F., Machfoed, M., Darwin, A., Song, A. \& Karyana, M. (2014). Indonesia Stroke Registry (S12.003). Neurology, 82.

Carolee, W., J, Stein, J., Arena, R., Bates, B., Cherney, R., Cramer, C., Deruyter, F., Eng ., J., Fisher, B., Harvey, L., Lang, E., MacKay-Lyons, M., Ottenbacher, J., Pugh, S., Reeves, J., Richards, G., Stiers, W. \& Zorowitz, D. (2016). Guidelines for Adult Stroke Rehabilitation and Recovery. Stroke, 47(6), pp e98-e169.

Catangui, E.J. \& Slark, J. (2012). A thrombolysis pathway for patients following acute ischaemic stroke, Nursing Standard, 26(31), pp 35-42.

Chaidir, R. \& Zuardi, I.M. (2014). Pengaruh Latihan Range of Motion Pada Ekstremitas Atas Dengan Bola Karet Terhadap Kekuatan Otot Pasien Stroke Non Hemoragi Di Ruang Rawat Stroke RSSN Bukittinggi tahun 2012. AFIYAH, 1(1).

Coleman, E.R., Moudgal, R., Lang, K., Hyacinth, H.I., Awosika, O.O., Kissela, B.M. \& Feng, W. (2017). Early Rehabilitation After Stroke: A Narrative Review. Current Atherosclerosis Reports, 19(12), pp 59.

Feigin, V., Nichols, E., Alam T., Bannick, M., Beghi, E. \& Blake, N. (2019). Global, regional, and national burden of neurological disorders, 1990-2016: A systematic analysis for the Global Burden of Disease Study 2016. The Lancet Neurology, 18(5), pp 459-480.

Finkelstein, E.A., Chay, J. \& Bajpai, S. (2014). The Economic Burden of Self-Reported and Undiagnosed Cardiovascular Diseases and Diabetes on Indonesian Households. PLOS One, 9(6).

Förster, A., Gass, A., Kern, R., Wolf, E., Ottomeyer, C., Zohsel, K., Hennerici, M. \& Szabo, K. (2009). Gender Differences in Acute Ischemic Stroke. Stroke, 40(7), pp 2428-2432.

Haast, R.A.M., Gustafson, D.R. \& Kiliaan, A.J. (2012). Sex Differences in Stroke. Journal of Cerebral Blood Flow \& Metabolism, 32(12), pp 2100-2107.

Hickey, J.V. (2013). The Clinical Practice of Neurological and Neurosurgical Nursing, $7^{\text {th }}$ ed. Lippincott Williams \& Wilkins; Philadelphia.

Irfan, M. (2012). Fisioterapi Bagi Insan Stroke. Graha Ilmu; Yogyakarta.

Kamarul, T., Ahmad, T.S. \& Loh, W.Y.C. (2006) Hand Grip Strength in the Adult Malaysian Population. Journal of Orthopaedic Surgery, 14(2), pp 172-177.

Kelly-Hayes, M. (2010). Influence of Age and Health Behaviors on Stroke Risk: Lessons from Longitudinal Studies. Journal of the American Geriatrics Society, 58(s2), pp S325-S328.

Lindberg, P., Schmitz, C., Forssberg, H., Engardt, M. \& Borg, J. (2004). Effects of passive-active movement training on upper limb motor function and cortical activation in chronic patients with stroke: A pilot study. Journal of Rehabilitation Medicine, 36(3), pp 117-123.

McAniff, C.M. \& Bohannon, R.W. (2002). Validity of grip strength dynamometry in acute rehabilitation. Journal of Physical Therapy Science, 14(1), pp 41-46.

Michael, K.M. \& Shaughnessy, M. (2006). Stroke prevention and management in older adults. Journal of Cardiovascular Nursing, 21(5), pp 21-26.

Ministry of Health Indonesia 2018, Pusat Data dan Informasi Kesehatan Kementerian Kesehatan RI, Indonesia. Retrieved from: https://pusdatin.kemkes.go.id/

Oktraningsih, I. (2017). Gambaran Kekuatan Otot Pasien Stroke yang Immobilisasi di RSUP H. Adam Malik Medan. The University of Institutional Resipotiory. Retrieved from: http://repositori.usu.ac.id/handle/123456789/1531

Petersen, P., Petrick, M., Connor, H. \& Conklin, D. (1989). Grip strength and hand dominance: challenging the 10\% rule. 
American Journal of Occupational Therapy, 43(7), pp 444-447.

Prok, W., Gessal, J. \& Angliadi, L. (2016). Pengaruh latihan gerak aktif menggenggam bola pada pasien stroke diukur dengan handgrip dynamometer. $e$-CliniC, 4(1).

Rahmawaty, E., Handayani, S., Sari, M.H.N \& Rahmawati, I. (2019). Sosialisasi dan harmonisasi gerakan masyarakat hidup sehat (germas) dan program indonesia sehat dengan pendekatan keluarga (pis-pk) di kota sukabumi. Link, 15(1), pp 27-31.

Randolph, S.A. (2016). Ischemic Stroke. Workplace Health \& Safety, 64(9), pp 444.

Sunderland, A., Tinson, D., Bradley, L. \& Hewer, R.L. (1989). Arm function after stroke. An evaluation of grip strength as a measure of recovery and a prognostic indicator. Journal of Neurology, Neurosurgery, and Psychiatry, 52(11), pp 1267-1272.

Taekema, D.G., Gussekloo, J., Maier, A.B., Westendorp, R.G. \& de Craen, A.J. (2010). Handgrip strength as a predictor of functional, psychological and social health: A prospective population-based study among the oldest old. Age Ageing, 39(3), pp 331-337.

Trosclair, D., Bellar, D., Judge, L.W., Smith, J., Mazerat, N. \& Brignac, A. (2011). Hand-Grip Strength as a Predictor of Muscular Strength and Endurance. The Journal of Strength \& Conditioning Research, 25, pp S99.

Watila, M., Nyandaiti, Y., Bwala, S. \& Ibrahim, A. (2011). Gender variation in risk factors and clinical presentation of acute stroke, Northeastern Nigeria. Journal of Neuroscience and Behavioural Health, 3(3), pp 38-43.

Yazid, B. (2017). Gambaran kekuatan otot pasien stroke yang imobilisasi di rsup. H. Adam malik medan. Journal Keperawatan Flora, 10(1). 